\title{
Electrophoretic Pattern of Protein Molecules in Gut Associated Lymphoid Tissue of Prenatal Goat
}

\author{
Avnish Kumar Gautam ${ }^{1} *$, Uma Kant Mishra ${ }^{2}$ and Arun Kumar Mandal ${ }^{3}$ \\ ${ }^{1}$ Bihar Veterinary College, Patna, India \\ ${ }^{2}$ OUAT, Bhubaneswar, India \\ ${ }^{3}$ WBUAFS, Kolkata, India
}

*Corresponding author

\section{A B S T R A C T}

\section{Keywords}

Electrophoretic pattern, Lymphoid tissue, Prenatal goat

Article Info

Accepted:

04 January 2019

Available Online:

10 February 2019
Gut associated lymphoid tissue (GALT) extracts of prenatal goat were subjected to $12.5 \%$ SDS-PAGE. The study revealed that there was less variation among different age groups of prenatal goat in same GALT extract. Ileal and thymic extract of 99 and 112 days old prenatal goat fractioned into 12 protein whereas in 50 days old foetal goat one protein in ileal and two protein in thymic extract were missing. In splenic extracts of 112 days old foetus three protein bands were missing when compared to 50 and 99 days old goat foeti. The mesenteric lymph node in 99 and 112 days old foetus was studied and its molecular weight of proteins ranged from $161.5 \mathrm{Kd}$ to $16 \mathrm{Kd}$.

\section{Introduction}

Several pre-existing protein molecules play pivotal role in cell differentiation, maturation and proliferation.

Such protein moieties also provide the basis to cytoskeleton and also contribute to cellular secretion.

Thus a detailed electrophoretic pattern of protein molecules in thymic, splenic, mesenteric lymph node and ileum extracts will provide clues for involvement of specific protein fractions during GALT development and maturation.

\section{Materials and Methods}

The samples were collected in aseptic conditions from local slaughterhouse in Bhubaneswar and transported to the laboratory maintaining cold chain.

GALT like Spleen, thymus, ileum, and mesenteric lymph nodes were isolated from goat foeti aging 50, 99 and 112 days of gestation and stored at $-25^{\circ} \mathrm{C}$ till further use. 


\section{Tissue extraction}

$2 \mathrm{~g}$ of each sample was taken and mixed with $2 \mathrm{ml}$ of PBS, pH 7.2 containing $2 \mu \mathrm{l}$ of $1 \mathrm{mM}$ PMSF (phenyl methyl sulfonyl fluoride) solution and then homogenized properly under chilled condition. Samples were collected in Eppendorf tube and centrifuged in $16000 \mathrm{rpm}$ for 10 minutes at $4^{\circ} \mathrm{C}$. The supernatants were collected in cryovials in different aliquots and stored at $-25^{\circ} \mathrm{C}$ till further processing.

SDS-PAGE of gut associated lymphatic tissue extracts of prenatal goat was carried out as per the method of Laemmli (1970) with vertical mini slab gel system (Atto Ltd, Japan).

\section{Reagents}

Solution-A:

Acrylamide

Bisacrylamide

$29.2 \mathrm{gm}$

Made upto $100 \mathrm{ml}$ with distilled water

Solution-B:

1.5 M tris-HCL buffer, $\mathrm{pH} 8.8,0.4 \%$ SDS

Solution-C:

$1.5 \mathrm{M}$ tris-HCL buffer, $\mathrm{pH}$ 6.8, 0.4\% SDS

Solution-D:

$10 \%$ ammonium persulphate prepared fresh.

Solution-E:

$0.05 \mathrm{M}$ tris $0.192 \mathrm{M}$ glycine, $0.1 \% \mathrm{SDS}, \mathrm{pH}$ 8.3.

Solution-G:

Loading buffer

Glycerol -2 ml

2- mercaptoethenol -1 ml

$10 \%$ SDS $-4.5 \mathrm{ml}$

Upper buffer $-1.7 \mathrm{ml}$

$0.1 \%$ Bromophenol blue $-0.2 \mathrm{ml}$

Distilled water $-0.6 \mathrm{ml}$

Mixed and stored at $-20^{\circ} \mathrm{C}$

\section{Preparation of gel}

\begin{tabular}{|c|c|c|c|c|c|}
\hline Gel concentration & & & $15 \%$ & \multicolumn{2}{|c|}{ Stacker gel 5\% } \\
\hline Solution-A: (ml) & & & 18 & & \\
\hline Solution-B: (ml) & 9 & 9 & & 9 & -- \\
\hline Solution-C: (ml) & -- & -- & & -- & 3 \\
\hline Solution-D: (ml) & 0.14 & 0.14 & & 0.14 & 0.036 \\
\hline TEMED (ml) & 0.02 & 0.02 & & 0.02 & 0.012 \\
\hline Distilled water (ml & 15 & 12 & & 9 & 7.2 \\
\hline
\end{tabular}

\section{Casting of gel}

$12.5 \%$ gel solution as per the Table 1 was prepared and poured carefully into gel casting space between the glass plates until about $75 \%$ of the space volume was filled. Water saturated n-butanol was layered over the gel and after polymerization of the separating gel; n-butanol was drained off by tilting the gel cast assembly. The gel upper surface was then washed with distilled water to remove nbutanol, if any. 5\% stacking gel solution was layered over the separating gel after washing the upper surface by the same gel solution. 
Slot forming comb was carefully inserted into the top of the gel casting area until both ends of the comb were stopped at top of the sidespacer. Water saturated n-butanol was over layered. After polymerization of stacker gel, the comb was removed slowly and carefully and the wells were washed thoroughly with solution E.

\section{Preparation of sample}

The GALT crude extracts prepared earlier were mixed with solution-G in 1:1 proportion and the samples were boiled for 5 minutes in hot water bath and cooled down to be used for loading.

\section{Electrophoretic run}

Samples were applied to each slot so that amount of protein was about $40 \mu \mathrm{g}$ in each case. Electrophoresis was performed at a constant voltage mode of 80 volts/slab for 20 minutes and was increased to 120 volts/slab subsequently till the tracking dye reached the lower end of the gel. Electrophoresis was carried out at room temperature.

\section{Staining and destaining of gels}

The gels after electrophoresis were stained with the staining solution i.e. $0.25 \%$ coomassie brilliant blue R-250 in $10 \%$ glacial acetic acid and $50 \%$ methanol solution for 4 hours. The gels were then destained with several changes of $10 \%$ acetic acid and $40 \%$ methanol in distilled water. After through destaining the gels were stored in $7 \%$ acetic acid till photographed.

\section{Determination of molecular weight by SDS-PAGE}

Protein markers like Myosin-rabbit muscle, Phosphorylase- $b$ Bovine serum albumin, Ovalbumin, Carbonic anhydrase, Soyabin trypsin inhibitors, Lysozyme, Aprotinin and
Insulin having molecular weight $205 \mathrm{kd}, 94.7$ kd,66 kd, 43 kd, 29 kd, $20.1 \mathrm{kd}, 14.3 \mathrm{kd}, 6.5$ $\mathrm{kd}$, and $3 \mathrm{kd}$ respectively were used. The mobilities of all the proteins and peptides were recorded as:

Relative mobility $=$

Length of gel before staining

Distance of dye migration before staining

$\mathrm{X}=$

Distance of protein migration after destaining

Length of gel after destaining

The standard curve was plotted by relative mobilities of the standard marker proteins against their corresponding log molecular weights from which the molecular weight of unknown proteins were calculated by plotting their corresponding relative mobilities in the graph.

Determination of molecular weight of GALT extracted proteins by SDS -PAGE

The molecular weights of different GALT extracted proteins of prenatal goats of various age groups were estimated by using molecular weight marker (Genei cat No.-PMW-H), by plotting the log molecular weights of the standard proteins against the corresponding $\mathrm{Rm}$ values (Fig. 2) and comparing the Rm value of unknown protein bands with the graph for the corresponding molecular weights. The molecular weights of unknown protein thus found out are illustrated in Table 1.

\section{Results and Discussion}

GALT extracts of prenatal goats were subjected to $12.5 \%$ SDS-PAGE to study the relative distribution of different proteins in various GALT of different age groups (Fig. 
1). From the electrophoretic pattern it was clear that the ileum extracts of 99 and 112 days old goat foetus were resolved into 12 protein bands where as that of 50 days old ileum extract was fractioned into 11 bands. The molecular weight of ileum extracted protein of prenatal goats irrespective of age group ranged from $161.5 \mathrm{kd}$ to $16 \mathrm{kd}$ but in 50 days old goat foeti ileum there was missing of one protein having molecular weight of 64.5 kd. Wang and Hasnain (2017) reported that the Murine intestinal mucins are large heavily glycosylated proteins and typically have a molecular mass higher than $1000 \mathrm{kd}$. In case of spleen extracted protein the molecular weight also ranged from $161.5 \mathrm{kd}$ to $16 \mathrm{kd}$, but three protein bands with molecular weights 131,81 and $72.5 \mathrm{kd}$ were not present in 112 days old prenatal goat spleen extract. Cunningham and Tang (1976) revealed that the molecular weight of cathepsin $\mathrm{D}$ in porcine spleen ranged from 34 to $35 \mathrm{kd}$. Donella-Deana et al., (1996) isolated 57-kDa protein substrate of the tyrosine kinase Lyn from rat spleen.

Table.1 Molecular weight (Kd) of GALT extract in prenatal goat by SDS-PAGE (with age)

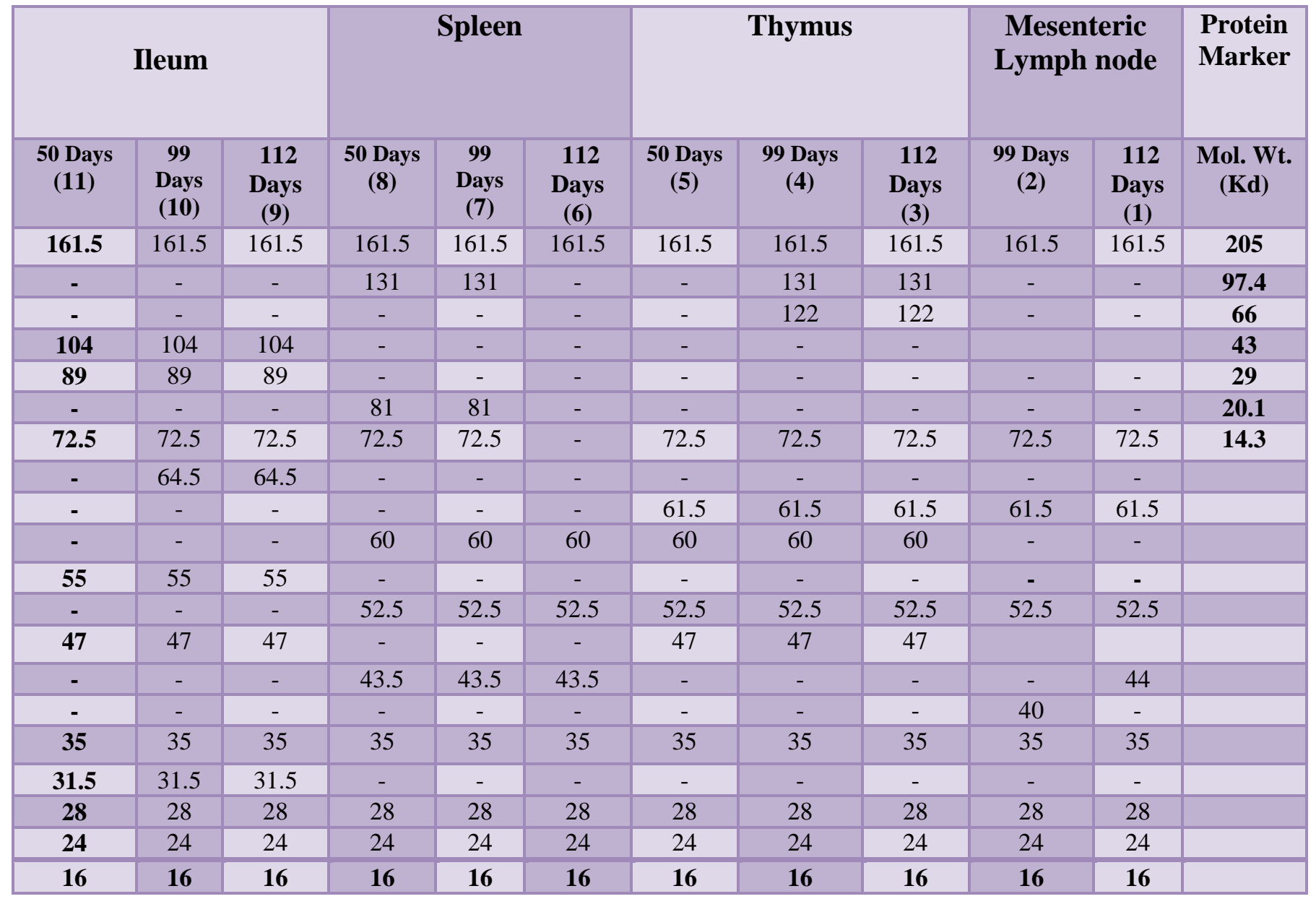

* The number within parentheses indicates the sample type and corresponds to the number indicated in SDS PAGE (Fig. 1) 
Fig.1 SDS - PAGE (12.5\%) of GALT extract of prenatal goat

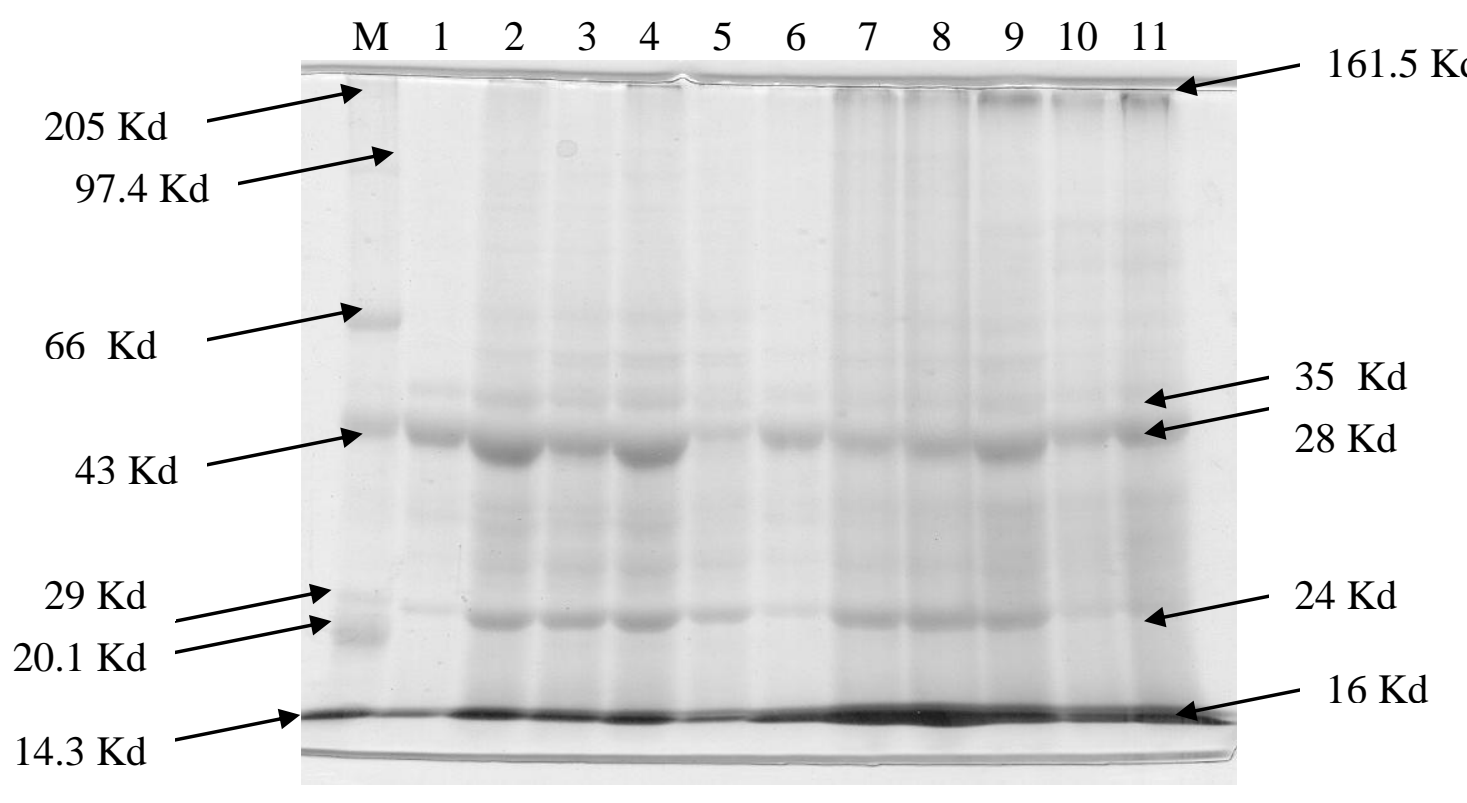

Fig.2 Calibration curve for Molecular weight estimation by SDS - PAGE

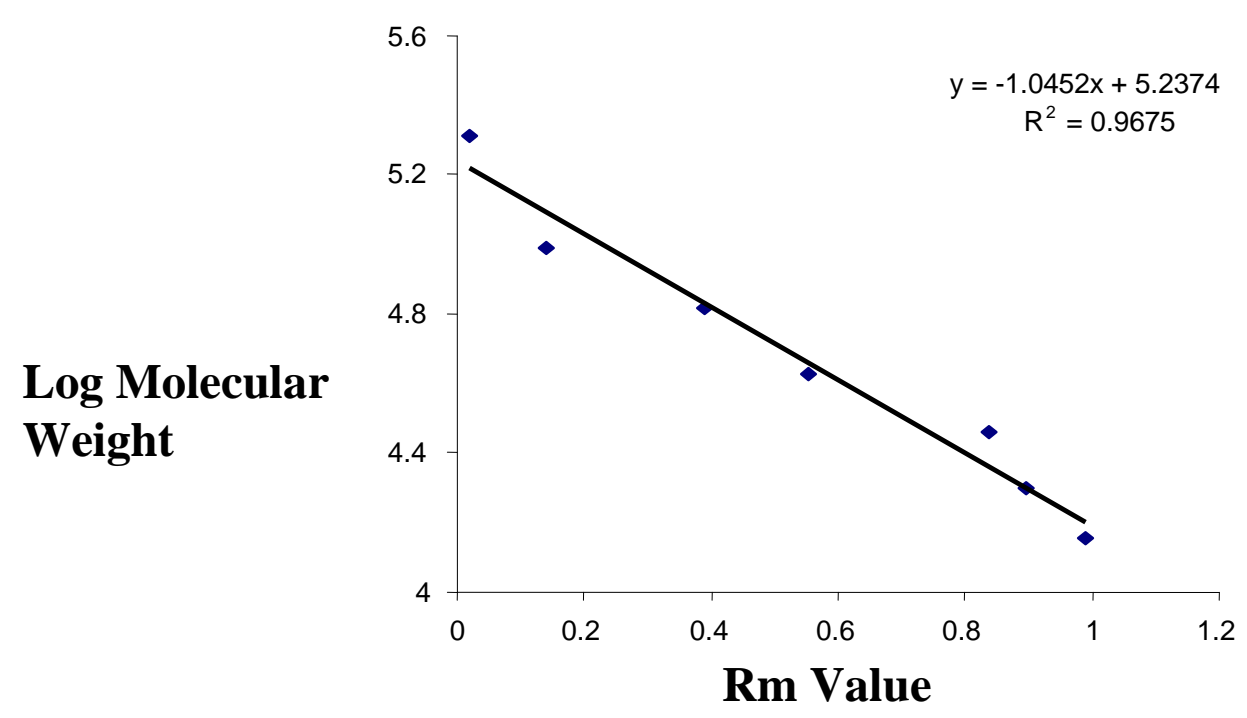

In thymus extract the molecular weight also ranged from $161.5 \mathrm{kd}$ to $16 \mathrm{kd}$, but in 50 days old prenatal goat foetal thymus there was absence of two proteins having molecular weight of 131 and $122 \mathrm{kd}$. Rong and Carl (1990) observed that molecular weight and subunit composition of calf thymus ribonuclease $\mathrm{H} 1$ enzyme either was single polypeptide of $74 \mathrm{kd}$ or consisted two to four subunit in the range of $21-34 \mathrm{kd}$. In mesenteric lymph node extract the molecular weight ranged from 161.5 to $16 \mathrm{kd}$. In both the age groups studied but there is only variation in one protein. The presence of many protein bands in lower molecular weight range might be due to proteolysis of the proteins after extraction. The low molecular weight range proteins could be well resolved by using 
gradient gel of higher concentration. In the present study the proteins having molecular weight $16 \mathrm{kd}$ could only resolved. The proteins/peptides having lower molecular weight were also present which might be responsible for the innate immunity in the mucosal layers of these tissues.

\section{References}

Cunningham, $\mathrm{M}$ and Tang, J. 1976. Purification and Properties of Cathepsin D from Porcine Spleen. The Journal of Biological Chemistry, 251(15) Issue of August 10, pp. 45284536.

Donella-Deana, A., James, P., Staudenmann, W., Cesaro, L., Marin O, Brunati, A.M., Ruzzene, $\mathrm{M}$ and Pinna, L.A.1996. Isolation from spleen of a
$57-\mathrm{kDa}$ protein substrate of the tyrosine kinase Lyn. Identification as a protein related to protein disulfideisomerase and localisation of the phosphorylation sites. Eur J Biochem. Jan 15;235(1-2):18-25.

Laemmli, U.K. 1970. Cleavage of structural proteins during the assembly of the bacteriophage $\mathrm{T}_{4}$. Nature 227; PP: 680-685.

Rong, W.Y and Carl, L.P. 1990.On the molecular weight and subunit composition of calf thymus ribonuclease H1.Biochemistry,29 (2), pp 383-389.

Wang, R and Hasnain, Z.S. 2017. Analyzing the Properties of Murine Intestinal Mucins by Electrophoresis and Histology. Bio Protoc.7 (14) Jul 20.

\section{How to cite this article:}

Avnish Kumar Gautam, Uma Kant Mishra and Arun Kumar Mandal. 2019. Electrophoretic Pattern of Protein Molecules in Gut Associated Lymphoid Tissue of Prenatal Goat. Int.J.Curr.Microbiol.App.Sci. 8(02): 215-220. doi: https://doi.org/10.20546/ijcmas.2019.802.026 